\title{
Public Speaking Syllabus Evaluation and Needs Analysis as the Identity of School With Entrepreneurship Profile
}

\author{
Eric Estha Dahana* \\ Graduate Student of Linguistic Department \\ Universitas Indonesia \\ Depok, Indonesia \\ erickempay83@gmail.com
}

\begin{abstract}
Among four macro skills of language, speaking is considered as the main measurement of learning language in both first and second language learning contexts. Every day the average person spends about 25 percent of time speaking and listening to other people. Nevertheless, based on the polling, the biggest fear of most people is that to speak in front of public. Regarding to this, aiming to enhance students' speaking skill and develop their communication effectively, as well as to reduce anxiety level of speaking in front of lots of people, a private school in Jakarta, named Citra Kasih Senior High School, held a special class entitled Public Speaking Class. Thus, regarding to the specific purpose, this study tried to analyze the needs of Public Speaking learning and to evaluate the ongoing program. The needs analysis was conducted at the school of twenty students in grade twelve as the last grade of senior high school in order to get a more holistic summary of the three years learning period. The results of this questionnaire stipulated that the public speaking class still has redundancy on the taught materials in which some are not included as public speaking and that a gap between English and public speaking classes does exist. According to these findings, more established syllabus and methods are required, considering that this kind of particular school subject remains difficult to be found in other high schools, especially in Indonesia. Recommendations and pedagogical implications are suggested for the betterment of public speaking learning program for senior high school.
\end{abstract}

Keywords-Public Speaking, English for Specific Purposes, Needs Analysis

\section{INTRODUCTION}

English for Specific Purposes (ESP) is a language teaching approach that aims for the academic and workplace needs of learners in the future. The focus of ESP is on language, skills, discourse, and genres (spoken or written) that support learners to meet their learning needs through general teaching or certain disciplines and learning methodologies [1]. Thus, ESP helps students to develop their language skills, specifically for pragmatic purposes, such as further study and certain professions [2]. In general, more than a half of the world's foreign student population $(53 \%)$ comes from the Asian continent which concentrated in Anglophone countries such as the United States of America, United Kingdom and Canada as priority destinations. On that basis, the teaching of English with ESP approach is highly necessary for high school level learners to prepare them for their future studies and professions. Referring to language learning goals categorization, English for Specific Purposes (ESP) embodiment as a learning approach is significant in educational institutions that have professional areas or have certain profiles.

Conceptually, there are two main areas of ESP, namely English for Academic Purposes (EAP) and English for Occupational Purposes (EOP). English language learning for high school level is generally centered on EAP; as a preparation for students to enter tertiary education. Nevertheless, often times English language learning application is also to develop students' skills in certain fields according to their interests and needs. The term EOP refers to learning English outside of academic needs. This study made English for Business Purposes (EBP), which is part of EOP, a representation of a school with entrepreneurship as its identity and nomenclature. To find out the needs of learners in learning English, Citra Kasih senior high school held a program of public speaking class with ESP approach, covering both academic and entrepreneurship purposes. In the current era of globalization, it cannot be denied that English has become an international language of instruction which certainly plays an important role in expanding social networking and developing effectiveness in the field of entrepreneurship.

As a method of learning speaking skills, public speaking in teaching English for business purposes cannot be ruled out [3]. Entrepreneurship also has a close relationship with innovation and anticipation of things or problems that may not have happened now but are predicted to occur in the future, such as the need for mastery of public speaking skills for the younger generation. This implies the significance and urgency of learning public speaking, especially to develop audience persuasion skills [4]. Ironically, even though every day the average person spends $25 \%$ of their time talking and listening to others, the biggest fear for most people is to speak in front of public [5]. On the contrary, public speaking skill has become a vital aspect and real communicative needs, especially in the workplace. In Indonesia context especially, it is clearly seen that public speaking is an area that is still poorly prepared by school or college graduates. If the skills of public speaking are taught and trained in higher education, it will be a little bit late 
because the learners already need these skills in the learning process.

Citra Kasih senior high school, a school with entrepreneurship identity, saw this future need of public speaking skill mastery for students before entering higher education. Nevertheless, the program that had been run for years seemed haven't fulfilled the students' needs and sufficiently taught the students entrepreneurship public speaking skills.

The above introduction led to these research questions:

1) What are the students' needs in learning public speaking?

2) How is the evaluation towards the ongoing public speaking program, particularly regarding to developing entrepreneurial skills?

\section{METHOD}

\section{A. Data Collection Instruments}

Needs analysis was used in this study to gain information from the students about the learning process of public speaking, particularly related to their entrepreneurial verbal communication skill development. Data was gathered via questionnaires for the students and interview with the teacher of public speaking.

\section{B. Participants}

There are twenty students of twelve grade examined in this study. Grade twelve students were chosen because this level is the last level of school phase before the students enter university and they had learned public speaking for three consecutive years. The public speaking class itself is held from grade ten and has been a fixed subject in the school. In a year, there are thirty-six meetings of public speaking program for each grade ten and eleven, while for grade twelve there are thirty-two meetings.

\section{Data Analysis}

The questionnaire data is calculated based on the frequency of the answers and the form is agreeing or disagreeing towards statements. Perception is positive if the percentage of answers is more than $40 \%$, and negative is $40 \%$ and below. Meanwhile the interview data was analyzed using narrative analysis to highlight important aspects and critical points that would best resonate with the areas of the research.

\section{RESULTS}

\section{A. Public speaking class needs analysis}

In the school, the public speaking class had been taught since the students were in grade ten, so they have studied it for more than two years. To fulfill their future needs, by learning public speaking the students were expected to get themselves more prepared to enter universities or workplace. Fig. 1 below shows the analysis of students' needs for learning public speaking.

\begin{tabular}{|l|c|c|c|}
\hline \multicolumn{1}{|c|}{ Statements } & N & Agree & Disagree \\
\hline $\begin{array}{l}\text { Learning public speaking is important to } \\
\text { continue education to a higher level }\end{array}$ & 20 & $\begin{array}{c}20 \\
(100 \%)\end{array}$ & $\begin{array}{c}0 \\
(0 \%)\end{array}$ \\
\hline $\begin{array}{l}\text { Learning public speaking is important to } \\
\text { work }\end{array}$ & 20 & $\begin{array}{c}19 \\
(95 \%)\end{array}$ & $\begin{array}{c}1 \\
(5 \%)\end{array}$ \\
\hline $\begin{array}{l}\text { I want to learn public speaking to } \\
\text { develop my speaking skill }\end{array}$ & 20 & $\begin{array}{c}20 \\
(100 \%)\end{array}$ & $\begin{array}{c}0 \\
(0 \%)\end{array}$ \\
\hline $\begin{array}{l}\text { I want to learn public speaking to } \\
\text { develop my English knowledge }\end{array}$ & 20 & $\begin{array}{c}19 \\
(100 \%)\end{array}$ & $\begin{array}{c}1 \\
(0 \%)\end{array}$ \\
\hline
\end{tabular}

Table 1. Public speaking needs analysis

From the results of the analysis above it can be concluded that the students believe that learning public speaking is useful and became their need to enter university or workplace. Aside from that, it became their wants that learning public speaking would enrich their knowledge of English and specifically can develop their speaking skills as one of the productive skills of language.

\section{B. Entrepreneurship public speaking}

In educational institutions that apply the concept of entrepreneurship as the basic value that goes hand in hand with the learner academic concepts development, the English for Specific Purpose (ESP) method based on entrepreneurship is certainly significant and becomes a supportive instrument for optimizing student learning outcomes. Fig. 2 below shows the students' perception on learning public speaking to improve their entrepreneurial skill as the identity of the school.

\begin{tabular}{|l|c|c|c|}
\hline \multicolumn{1}{|c|}{ Statements } & N & Yes & No \\
\hline $\begin{array}{l}\text { Learning public speaking helped me to } \\
\text { develop my entrepreneurial skills }\end{array}$ & 20 & $\begin{array}{c}6 \\
(30 \%)\end{array}$ & $\begin{array}{c}14 \\
(70 \%)\end{array}$ \\
\hline
\end{tabular}

Table 2. Entrepreneurship public speaking

The above result illustrates that although this school is based on entrepreneurship which has close relevance with public speaking, students have not yet benefited optimally from learning public speaking to develop their entrepreneurial skills.

\section{Public speaking program evaluation}

The existence of the syllabus is fundamental as a guidance to the learning process. Therefore, correlation between the needs of students and the programs implemented is needed, accompanied by an appropriate syllabus to support the learning process. In the reality, any teaching material must involve several syllabi at the same time and there are no perfect teaching methods. All must undergo an evaluation and development process. Fig. 3 below shows the students feedback on the teaching program unit as the syllabus resemblance.

\begin{tabular}{|l|c|c|c|}
\hline \multicolumn{1}{|c|}{ Statements } & N & Yes & No \\
\hline $\begin{array}{l}\text { An explanation about teaching program } \\
\text { unit of public speaking class was given } \\
\text { before the class began }\end{array}$ & 20 & $\begin{array}{c}0 \\
(20 \%)\end{array}$ & $\begin{array}{c}20 \\
(100 \%)\end{array}$ \\
\hline
\end{tabular}

Table 3. Public speaking teaching program unit 
The conclusion got from the table is that the public speaking learning syllabus for the school is not yet available and has not been systematically explained according to the concepts that exist. This result is reinforced by the teacher's statement in the interview with a question about the syllabus used in the public speaking class:

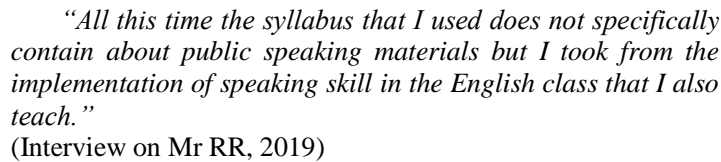

"All this time the syllabus that I used does not specifically contain about public speaking materials but I took from the implementation of speaking skill in the English class that I also teach."

(Interview on Mr RR, 2019)

The citation above gives an illustration of the unavailability of public speaking syllabus that supports the learning program. This makes the teacher to teach the material according to his own concept and understanding towards public speaking. This can also be seen from his statement on question about the material taught in public speaking classes:

"Well, basically I began my lessons in PS first the drill about pronunciation and in that lesson I teach students the pronunciation technique so that when they go to a deeper lesson they are moreprepared. Fo the individual presentation, I gave them the task of retelling the biography of the famous person in the world, like the billionaires, scientists, and stuffs. And for the group presentation I gave them a particular topic. For example, they're going to report about the wonders of the world, the second example, the Seven Wonders of the World, and in a group of five they are going to present the particular topic in such a way that a teacher teaches in the classroom. I think that's it."

(Interview on Mr RR, 2019)

From the above quotation, it can be concluded that the public speaking learning materials have not been specific in reference to a particular concept or theory and have not yet led to the development of public speaking entrepreneurship skills.

\section{CONCLUSION}

Based on the results of the needs analysis obtained, the students need public speaking learning to prepare themselves before entering higher education level or the workplace. The students also believed that learning public speaking had helped them to improve their speaking skills as much as to develop their English knowledge.

On the other hand, related to Citra Kasih School's identity as an entrepreneurship-based school, the students expected that public speaking learning might develop their entrepreneurial public speaking skills related to English for Business Purposes (EBP). The students also believed that entrepreneurship public speaking skill would increase their chances to expand their network with new people.
Meanwhile, regarding to the syllabus usage, it can be concluded that for all this time the public speaking class had not been taught based on a fixed public speaking syllabus intended for high school students.

According to the results of data calculations about public speaking program, the students believe that the learning would prepare them better for their future, especially when they enter higher education levels or workplaces. However, students need a more systematic teaching of public speaking; with a syllabus explaining what materials they will learn in the class.

Responding to this, recommendations and pedagogical implementation are suggested for creating a negotiated syllabus for public speaking class that emphasizes English for entrepreneurship purposes which should be taught systematically. Therefore, this study could be of much help for stakeholders, such as education institution foundations and school principals, ESP curriculum developers, ESP researchers, public speaking teachers or trainers, and educational policy makers.

Learning speaking skill using public speaking method, specifically public speaking in the field of entrepreneurship, is expected to be introduced and taught to high school students to equip and prepare the students for their future and to face global competition which sets English as the medium of instruction. Further research on documents analysis and public speaking syllabus model for senior high school is suggested.

\section{ACKNOWLEDGMENT}

High gratitude be to Ms. Sisilia Halimi as my advisor, for her guidance during my study. I would also like to thank my colleagues in Applied Linguistic program of language teaching, University of Indonesia.

\section{REFERENCES}

Anthony, L. (2015). The changing role and importance of ESP in Asia. English as a global language education (EaGLE). 1(1), pp. 01-21.

Dudley-Evans, T.,\& St. John, M.J. (1998). Developments in english for specific purposes. Cambridge, UK: Cambridge university press.

Zanola, A. (2016). Business communication and public speaking in the ESP domain: Some consideration. Linguistics and literature studies. 4(5), pp. 331-335.

Kahn, J.E., Kerr-Jaret, A., Cohen, A., Davies, P., Jones, N., Kahn, O., et al. (1991). Reader's digest how to write and speak better. New York, USA: The reader's digest associaton.

Janulevičiene, V dan Kavaliauskienė, G. (2011). English for specific purposes \& public speaking. Comparative study. Societal studies journal. 3(2), 709-720.

Boonkita, K. (2010). Enhancing the development of speaking skills for nonnative speakers of English. Procedia social and behavioral sciences 2 (2010) 1305-1309. 